\title{
MANUFACTURING AND EVALUATION OF PROTOTYPE FOR MELON SEED EXTRACTION
}

\section{Neamtallah ${ }^{1}$ R. Kholief ${ }^{2}$ R. A. Hegazy ${ }^{3}$ I. Abdelmotaleb ${ }^{4}$}

\begin{abstract}
\end{abstract}
Manual extraction process of melon seed is the most-used method in Egypt and requires large number of labors. In addition to high cost associated with the manual extraction. So, this research therefore developed locally manufactured prototype to mechanically extract seeds from melon with lower cost and higher productivity. The manufactured prototype consists of frame, feeding hopper, crushing and extracting unit, peels outlet, conveying auger of seeds, cleaning brushes and seeds outlet. Proposed prototype was tested and evaluated at Eletad village and Rice Mechanization Center (RMC), Agricultural Mechanization Research Institute, Ministry of Agriculture (Meet El Dyba, Kafr El-Sheikh governorate) during the year of 2015. The prototype evaluation done based on cleaning efficiency, extraction efficiency, machine productivity, power consumed, seed damaged and operational cost. Prototype evaluation was done at four different feeding rates $(20,30,40$ and 50 $\mathrm{kg} / \mathrm{min})$, five drum speeds $(3.25,5.47,6.98,8.52$ and $10.64 \mathrm{~m} / \mathrm{s})$ and four time spans $(0,3,6$ and 9 days). The results showed that the increase in crushing drum speed, melon seed time span and decreasing feed rate tend to decrease the cleaning efficiency, where the highest value of cleaning efficiency was $88.83 \%$ at crushing drum speed of $10.64 \mathrm{~m} / \mathrm{s}$, feed rate of $20 \mathrm{~kg} / \mathrm{min}$ and melon seed time span 9 days after harvesting. Also, the decrease of crushing drum speed, melon seed feed rate and increasing melon seed time span tend to increasing extraction efficiency, where the maximum value of extraction efficiency was $98.85 \%$ at crushing drum speed of $3.25 \mathrm{~m} / \mathrm{s}$, feed rate of $20 \mathrm{~kg} / \mathrm{min}$ and melon seed time span 9 day. Machine productivity increased by increasing feed rate, melon seed time span and decreasing crushing drum speed, where

\footnotetext{
${ }^{1}$ Assistant Researcher, Agric. Eng. Res. Inst., Dokki, Giza.

${ }^{2}$ Head Research, Agric. Eng. Res. Inst., Dokki, Giza.

${ }^{3}$ Associate Professor, Agric. Eng. Dept. Faculty of Agric. Kafrelsheikh University.

${ }^{4}$ Professor, Agric. Eng., Dept., Faculty of Agric., Kafrelsheikh University.
} 
maximum value of machine productivity was $152.14 \mathrm{~kg} / \mathrm{h}$ at crushing drum speed of $3.25 \mathrm{~m} / \mathrm{s}$, feed rate of $50 \mathrm{~kg} / \mathrm{min}$ and melon seed time span 9 day. Power consumption increased by increasing crushing drum speed, melon seed feed rate and melon seed time span, where the minimum value of power consumption was to $2.61 \mathrm{~kW}$ at crushing drum speed of $3.25 \mathrm{~m} / \mathrm{s}$, feed rate of $50 \mathrm{~kg} / \mathrm{min}$ and melon seed time span 9 day. Total costs increased by increasing crushing drum speed and decreasing both melon feed rate and melon seed time span, where the minimum value of total cost was $0.273 \mathrm{LE} / \mathrm{kg}$ at crushing drum speed of $3.25 \mathrm{~m} / \mathrm{s}$, melon seed feed rate of $50 \mathrm{~kg} / \mathrm{min}$ and melon seed time span 9 day.

\section{INTRODUCTION}

$\sqrt{\begin{array}{l}\text { elon seed (Colocynthiscitrullus) belongs to the } \\ \text { (Cucurbitaceae }) \text { family and is cultivated in the arid and semi- } \\ \text { arid areas of northern half of the Nile Delta in Egypt, such as }\end{array}}$ Kafr El-Sheikh Governorate and newly reclaimed land. Melon seed are strategic vegetable products in Egypt that can be exported to several Arab countries. Also, there are additional benefits from melon peels utilization as green fodder for animals, which represent about $0.33 \%$ from fruit mass ( $7 \mathrm{mg} / \mathrm{fed}$ as green fodder). In order to increase melon seed production and quality, researchers have realized the need to develop, use and improve modern melon extraction technology. According to Egyptian Ministry of Agriculture and Land Reclamation Report (2012), the total area of melon seed was 17500 fed1 with an average yield of 500-650 $\mathrm{kg} / \mathrm{fed}$. Melon seed extraction operations in Egypt are mostly accomplished by manual extraction. The traditional method of seeds extraction involves of cracking melon by cutting the head or tail monocarp and endocarp. The traditional method required large number of labors and high cost, where manual extraction process needs from 30 to 40 workers in a single day for one feddan and it costs about $1500 \mathrm{LE} / \mathrm{fed}$ (Eliwa and Elfatih, 2012). Yehia et al. (2009) mentioned that knowledge of the physical and mechanical characteristics of agricultural products is important in the design of agricultural machines and equipment. They studied the physical properties and characteristics of some agricultural

${ }^{1}$ An Egyptian unit of agriculture area, one faddan $=4200.83 \mathrm{~m}^{2}$. 
crops and fruits, which can be used in the design and development such equipment. Abou El-Magd et al. (2006) designed and evaluated equipment for extracting melon seed. They found that increasing feed rate tends to increase in seed losses with all variable levels. However, increasing feed rate from 60 to $90 \mathrm{~kg} / \mathrm{min}$ caused seed losses to increase from 4.49 to $5.68 \%$. Also, drum speed had considerably effect on seed losses. Seed losses increased from $3.83 \%$ to $6.90 \%$ when drum speed increased by 1.5 times, this trend may be due to the decreasing impact force of knives and the kinetic energy of the seeds which make seed more subjected to smashing forces. Abdrabo (2014) manufactured and evaluated melon seed extraction prototype and found that increasing melon seed feeding rates from 100 to $200 \mathrm{~kg} / \mathrm{min}$ decreased prototype efficiency from 97.01 to $94.65 \%$ at drum speed of $6.2 \mathrm{~m} / \mathrm{s}$ and 6 days after harvest, while increasing drum speed from 6.2 to $13.2 \mathrm{~m} / \mathrm{s}$ tended to increase the prototype efficiency from 93.5 to $94.65 \%$ at feeding rates $100 \mathrm{~kg} / \mathrm{min}$ and 2 days after harvest. The maximum prototype efficiency was $98.15 \%$ and was recorded at feeding rate of $100 \mathrm{~kg} / \mathrm{min}$, drum speed of $13.2 \mathrm{~m} / \mathrm{s}$ and 6 days after harvest. Egbe et al. (2015) evaluated and improved melon seed shelling machine of two seed types (yellow and white). It was found that both the feed rate and the soaking time had an effect on outcomes for both seed types. Feed rate of $12 \mathrm{~kg} / \mathrm{h}$ was optimal with the highest shelling efficiency and lowest percentage of broken seed with respect to water soaking (termed the critical spreading time). Amir (2004) designed and tested melon seed extraction machine, and found that drum speed had a great effect on seed losses under studied variables such as feed rate, drum-knives number and crushing time. He noticed that the increase in drum speed tended to increase the visible seed damage at all variables under the study. In addition, the period between harvesting and extraction process affected the visible seed damage. Oloko and Agbetoye (2006) developed and evaluated melon seed depodding machine. They found that the depodding efficiency machine was increase of 65.6 to $82.1 \%$ by increasing drum speed from 200 to 300 rpm. Tayel et al. (2010) found that the increment of spent time between harvesting and extracting process decreased seed damage. Also, they stated that the feed rate of $116 \mathrm{~kg} / \mathrm{min}$, drum speed of $2.48 \mathrm{~m} / \mathrm{s}$, drum concave clearance of $15 \mathrm{~mm}$, and 6 day of extracting after harvesting 
represent the minimum values of seeds damage. Eliwa and Elfatih (2012) developed and evaluated seed extractor prototype, they mentioned that maximum value of melon seed extraction efficiency $98.7 \%$ was obtained at a $250 \mathrm{rpm}$ flesh cutting unit speed, circular concave hole and two days span time after harvesting. Shreen (2014) fabricated seed extraction equipment to perform fruit crushing, seed extraction from the skin and other fruit material, skin releasing, and washing unit. Sobowale et al. (2015) designed and evaluated the performance of melon seed sheller machine. They showed that shelling speed of $1500 \mathrm{rpm}$ and moisture content of $18.32 \%$ led to best shelling efficiency of $76.30 \%$ and least percentage seed damage of $22.60 \%$ compared to shelling speed of $2500 \mathrm{rpm}$ and seed moisture content of $6.99 \%$ which had a shelling efficiency of $70.0 \%$ and percentage seed damage of $68.10 \%$. It was clear from the previous studies that there are drawbacks in the manufactured prototypes and in local industrial machine such as more seeds damage and poor seeds quality. So, the aim of this study was to manufacture a small prototype in order to perform the operation of seed extraction process of melon pulp with cleaning, and to reduce labors cost of seeds extraction process.

\section{MATERIALS AND METHODS}

\subsection{Manufacturing and experimental layout}

The prototype was fabricated with locally available materials at a private workshop in Kafr El-Sheikh governorate. A $25.8 \mathrm{~kW}$ tractor (Master TST350) was used to power the prototype through PTO shaft. The field experiments were carried out at El-Etahad village, Kafr El-Sheikh governorate during the year of 2015. In these experiments, melon Giza 5 variety was used and the total planted area was 2 feddans. The planted area was designed to meet the study requirements, where the experimental area divided to four main plots $(35 \times 60 \mathrm{~m})$, each main plot was divided into 60 sub-plots $(15 \times 35 \mathrm{~m})$ and each subplot was divided into 15 sub-sub plots $(5 \times 7 \mathrm{~m})$ to include three replications. The design criterion of manufactured prototype were: all parts to manufactured from locally available materials to reduce the cost and fit small and medium farms, the main purpose of the prototype to operate four processes (cutting, crushing extracting peel from the mixture of seed and flesh and 
cleaning of seeds) and the proposed prototype should be operated by tractor.

\subsection{Melon seed extraction prototype:}

The specifications of the melon seed extraction prototype are presented in Table 1 and sketched in Figure 1. The constructed machine for melon seed extraction consists of the following: Frame, feeding hopper, crushing and extracting unit, peels outlet, conveying auger of seeds, cleaning brushes and seeds outlet.
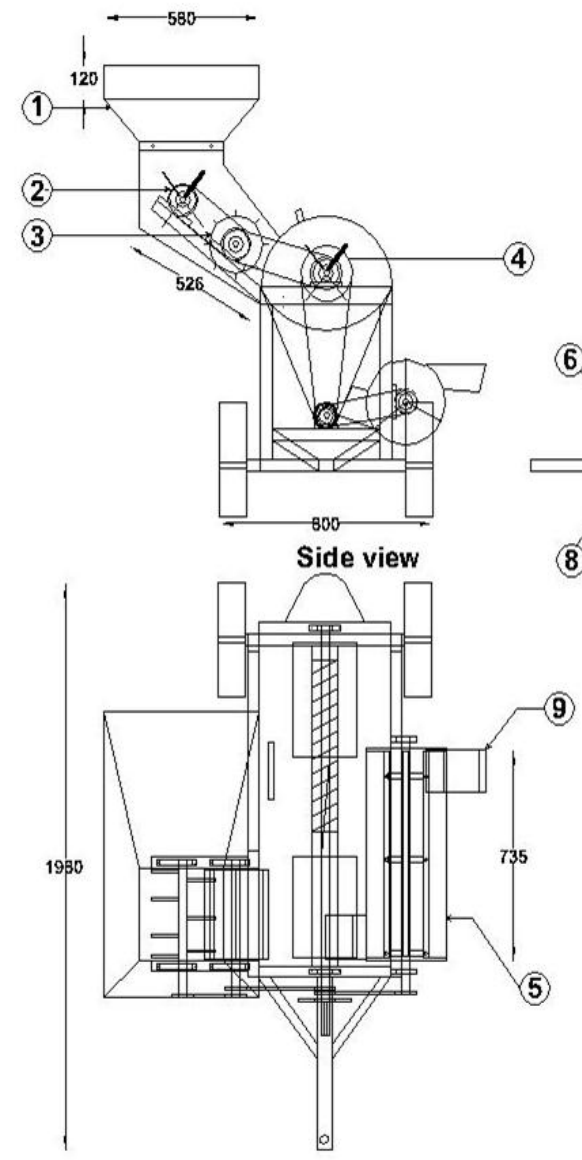

Plan

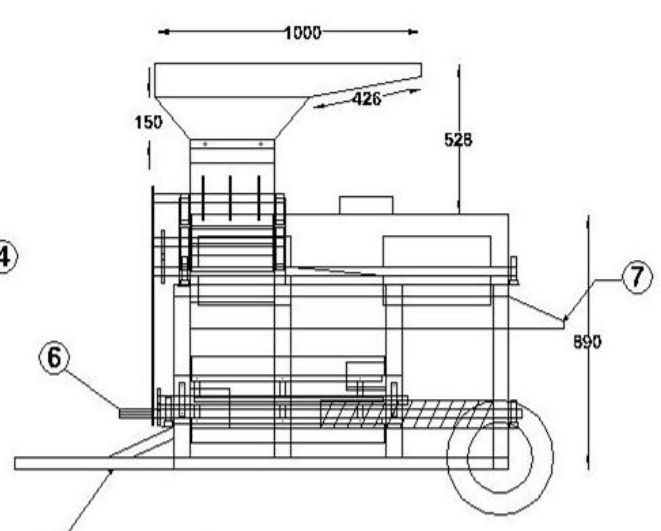

(8)

Elevation

\begin{tabular}{|c|l|}
\hline No. & Description \\
\hline 1 & Feed hopper \\
\hline 2 & Cutting drum \\
\hline 3 & Crushing drum \\
\hline 4 & Extraction drum \\
\hline 5 & Cleaning brushes \\
\hline 6 & Shit of operating machine \\
\hline 7 & Pulp outlet \\
\hline 8 & Frame \\
\hline 8 & Seed outlet \\
\hline
\end{tabular}

Dim . in mm

Scale 1:100

Figure 1: Schematic diagram of prototype of melon seed extraction.

\subsection{Crushing and extracting unit:}

The cutting, crushing and extracting unit consists of cutting, crushing and extraction drums beside the concave. 


\subsubsection{Cutting drum:}

Cutting drum was manufactured from steel with $225 \mathrm{~mm}$ diameter, $225 \mathrm{~mm}$ length and $5 \mathrm{~mm}$ thickness. Cutting drum was manufactured to be rotated at maximum speed of $1200 \mathrm{rpm}$ and a minimum speed of 350 $\mathrm{rpm}$, which is required to operate the machine. Figure 2 shows the schematic diagram of cutting drum.

\subsubsection{Crushing drum:}

Crushing drum was manufactured from steel with $150 \mathrm{~mm}$ diameter, 225 $\mathrm{mm}$ length and $5 \mathrm{~mm}$ thickness (Figure 3) Crushing drum was manufactured to be rotated at maximum speed of $1200 \mathrm{rpm}$ and a minimum speed of $350 \mathrm{rpm}$ which is required for operating machine and extracting seeds from melon. Crushing drum has hexagonal shape consists of 8 knives mounted on the circumference of the drum. It was manufactured to extract seeds from melon after cutting and to move the peel without seeds out of the machine.

Table 1: The technical specifications of manufactured seed melon extraction machine:

\begin{tabular}{|l|c|}
\hline \multicolumn{1}{|c|}{ Items } & Specification \\
\hline Manufacture & Locally workshop \\
\hline Total length, mm & 1980 \\
\hline Width, mm & 1250 \\
\hline Height, mm & 1300 \\
\hline Mass, kg & 210 \\
\hline Source of power & Tractor P.T.O. \\
\hline Feeding hopper of melon, mm & $400 \times 900 \times 100$ \\
\hline Length of the cutting cylinder, mm & 225 \\
\hline Diameter of the cutting drum, mm & 225 \\
\hline Number of cutting knives mounted on the drum & 8 knives \\
\hline Length of the crushing cylinder, mm & 225 \\
\hline Diameter of the crushing drum, mm & 150 \\
\hline Number of crushing knives mounted on the drum & 8 knives \\
\hline Length of the extraction cylinder, mm & 1000 \\
\hline Diameter of the extraction drum, mm & 180 \\
\hline Seeds outlet (length $\times$ width), mm & $120 \times 120$ \\
\hline Peels outlet diameter, mm & 400 \\
\hline
\end{tabular}



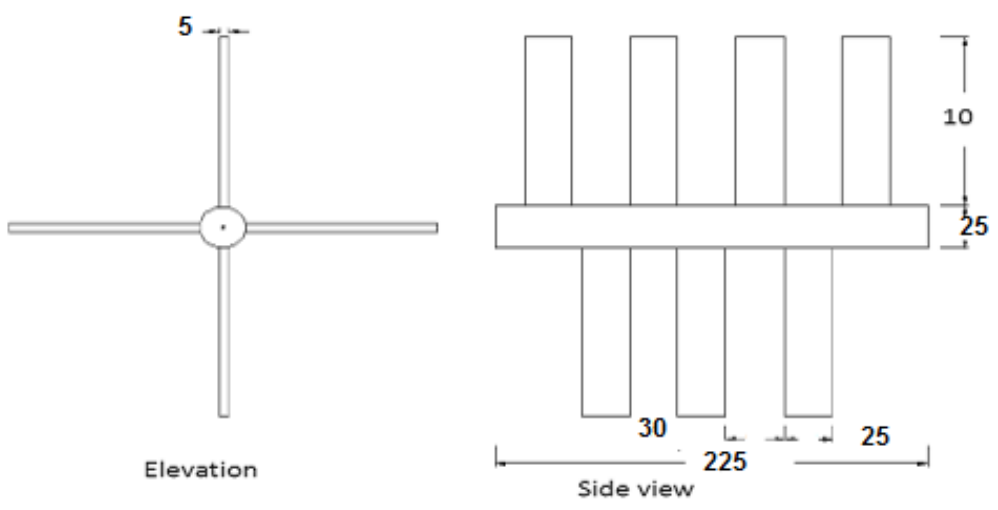

Dim. in $\mathrm{mm}$

Scale. $1: 100$

Figure 2: Schematic diagram of cutting drum

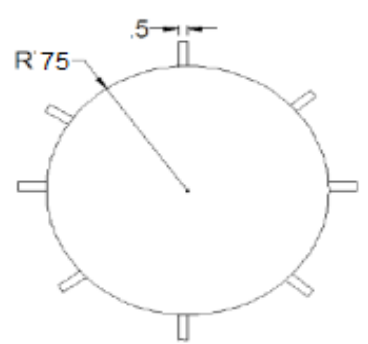

Elevation

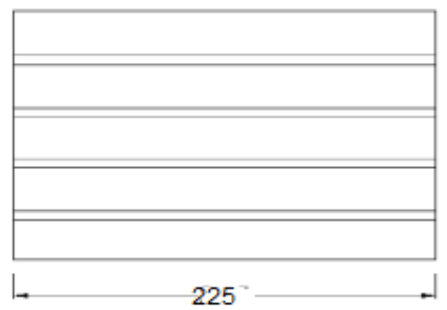

Side view

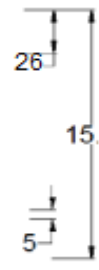

Dim. in $\mathrm{mm}$

Scale. $1: 100$

Figure 3: Schematic diagram of crushing drum.

\subsubsection{Extracting drum and cleaning brushes:}

Extracting drum with $180 \mathrm{~mm}$ in diameter and $1000 \mathrm{~mm}$ in length was fabricated from a $2 \mathrm{~mm}$ thick steel sheet and manufactured to be open at both ends to extract the seeds from the crushed melons that were fed into the extraction unit at one end of the drum. Extracted seeds were collected and received to the cleaning brushes while pulp and flesh moved axially through the drum up to its end. Number of 8 knives mounted on the extracting drum to gives best performance. This was similar to extraction drum designed by similar Amir (2004). Figure 4 shows the schematic diagram of crushing drum. The cleaning brushes dimensions are $40 \times 15$ 
$\mathrm{cm}$ each with $2 \mathrm{~cm}$ thickness. They are fixed to a steal bar and consist of 4 extraction parts to simplify the repair and maintenance operations of the brushes. At the end of cleaning brushes, there is an opening to collect the clean seeds in special pans.

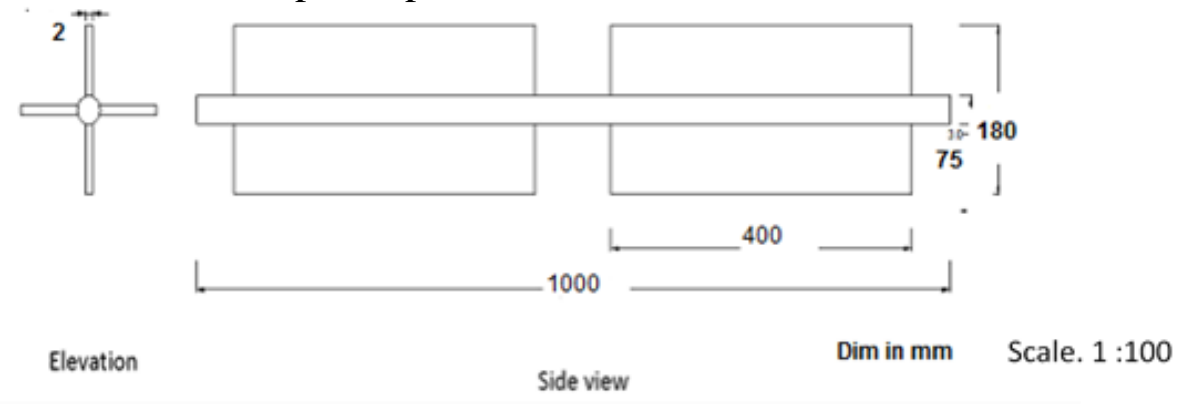

Figure 4: Schematic diagram of extraction drum.

\subsubsection{Concave}

It was manufactured and fabricated to move the seeds after extraction to cleaning brushes. The concave is a mesh of a semi-circle shape and is surrounding extracting drum. It constructed from a steel sheet of $3 \mathrm{~mm}$ thickness and its dimension was $\times 400 \mathrm{~mm}$ (length $\times$ width) with square openings of $18 \times 16 \mathrm{~mm}$.

\subsection{Frame and power transmission system}

The machine frame was fabricated from steel sheet $1000 \times 800 \times 70 \mathrm{~mm}$. It was manufactured to carry and hold all prototype' parts. The frame is mounted on two rubber wheels. A hitching bar was added and welded to the main frame to pull the machine during traveling. The balance of the machine is adjusted by elevating device welded to the hitching bar. The manufactured machine was driven by a transmission system connected to the P.T.O. of tractor (Master TST350, $25.8 \mathrm{~kW}$ ) by means of pair of pulleys, and a universal joint. The first pulley transmits the motion to the pulley of cutting and extracting drums and the second one transmits the motion to the pulley of cleaning unit as shown in Figure 5.

\subsection{Feeding hopper}

Drop type hopper that was designed to deliver the melons by gravity through an orifice to a revolving drum. The trapezoidal shape hopper had a rectangular intake upper opening of $1000 \times 400 \mathrm{~mm}$. The feeding hopper was manufactured and constructed from steel sheet $2 \mathrm{~mm}$ in thickness to feed melons into the crushing part. The size and shape of the 
hoper were determined from characteristic dimensions of melons. Figure 6 shows the feeding hoper connected to the prototype.

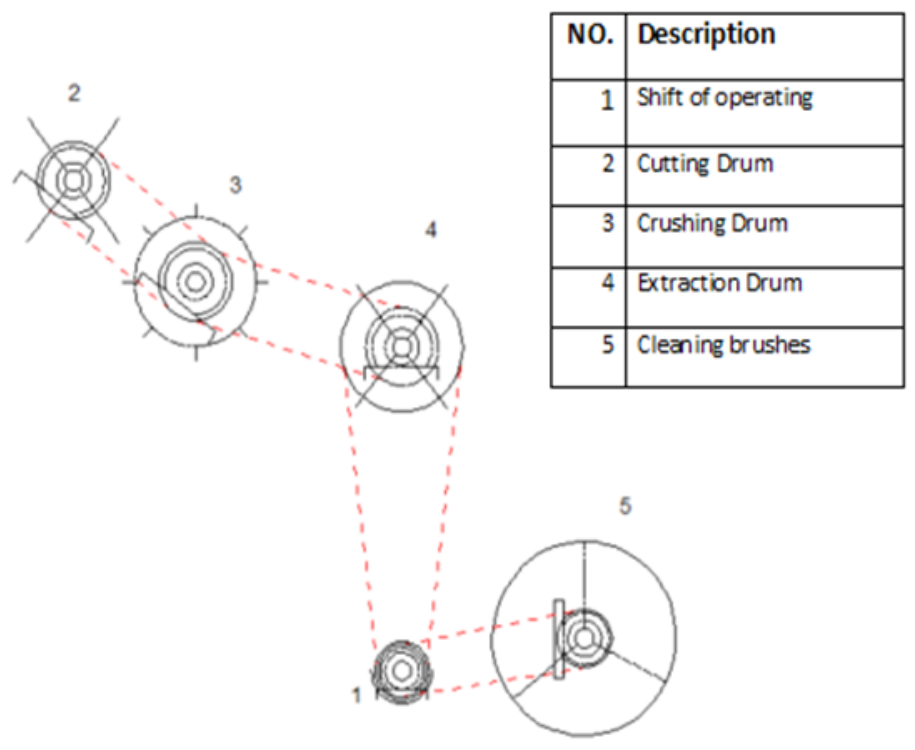

Figure 5: Schematic diagram of transmission system.

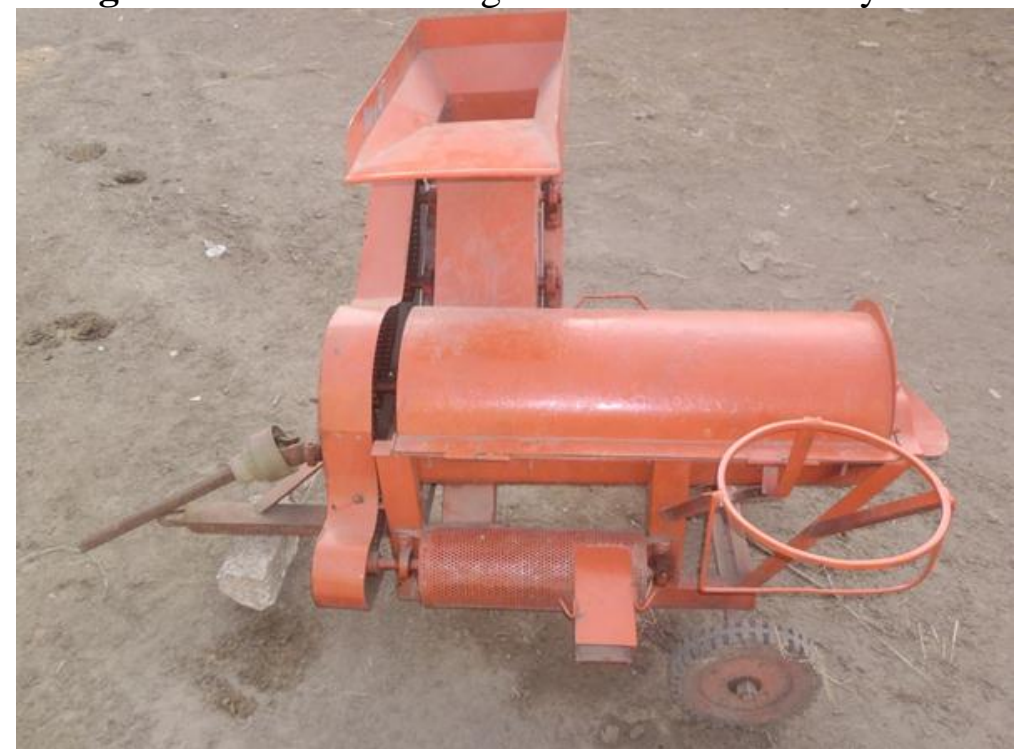

Figure 6: photograph of the feeding hoper connected to the prototype.

\subsection{Physical and mechanical properties.}

The physical and mechanical properties of melon seed were measured to collect the required information and to help in manufacturing the 
required prototype for seed extraction process. A number of 100 melon were randomly chosen from a farm at Kafr El-Sheikh governorate during the harvest year 2015to determine these properties as shown in Table 2.

Table 2: Physical and mechanical of melon seed:

\begin{tabular}{|l|c|}
\hline \multicolumn{1}{|c|}{ Characteristics } & Average \\
\hline 1. Dimensions: & \\
a) Melon diameter, mm & $350 \pm 35.5$ \\
b) Melon seed: & $16.21 \pm 0.99$ \\
$\quad$ - Length, mm & $10 \pm 0.25$ \\
$\quad$-Width, mm & $2.74 \pm 0.2$ \\
$\quad$ - Thickness, mm & $1205 \pm 139$ \\
2. Mass & $45.17 \pm 6.88$ \\
a) Mass of melon, g & 17190 \\
b) Mass of seeds, $\mathrm{g}$ & $1082.2 \pm 235.13$ \\
3. Average number of melon /fed. & $0.913 \pm 0.034$ \\
4. Volume of melon, $\mathrm{cm}^{3}$ & $1.12 \pm 0.13$ \\
5. Density of melon, $\mathrm{g} / \mathrm{cm}^{3}$ & $0.50 \pm 0.014$ \\
6. Density of seeds, g/cm & $60 \pm 5.78$ \\
7. Coefficient of friction of seeds & $3.55 \pm 0.2$ \\
8. Hardness of seed, $\mathrm{N}$ & \\
9. Terminal velocity of seeds, $\mathrm{m} / \mathrm{s}$ & \\
\hline
\end{tabular}

To determine the size of seeds, three samples of $0.5 \mathrm{~kg}$ each have been randomly chosen, from each sample, 200 seeds obtained and mixed, then, 100 seeds were randomly selected and labeled. This method of random sampling is similar to that followed by (Dutta et al., 1988). For individual seed, the three principal dimensions, namely: length, width and thickness were measured using a digital vernier, (accuracy of $0.01 \mathrm{~mm}$ ). Melon seed mass were determined by using electronic balance (accuracy of $0.01 \mathrm{~g}$ ). The hardness of seed was tested using rigidity tester (model \#174886 Kiya Seisakysho LTD). Mechanical properties were determined as the terminal velocity and static friction coefficient. Terminal velocity apparatus was used to measure terminal velocity according to Awady and El-Sayed (1994). The air flowed upwards in the tube from the bottom to top and the air velocity at which the major fraction of sample remained suspended was recorded by using an anemometer, where the repose angle was examined by using the digital 
apparatus at Rice Mechanization Center. The static friction coefficient (SFC) for seeds was calculated according to Abd El-Mageed and Abd Alla (1994) by using the following formula.

$$
\mathrm{SFC}=\tan \theta
$$

Where: $\mathrm{SFC}=$ Static friction coefficient and $\theta=$ repose angle, degree

The bulk density was calculated by dividing the mass of bulk seeds by its volume, which was measured by using a constant volume cylinder, the bulk density of seed was determined as:

$$
\mathbf{P}_{\mathrm{b}}=\frac{\mathrm{M}_{\mathrm{b}}}{\mathrm{V}_{\mathrm{b}}}
$$

Where: $P_{b}$ is the bulk density of seed, $\mathrm{g} / \mathrm{cm}^{3} ; M_{b}$ is the mass of seeds, $\mathrm{g}$ and $V_{b}$ is volume of the same seeds, $\mathrm{cm}^{3}$

\subsection{Productivity and efficiency of extraction prototype:}

Performance and evaluation of the prototype were studied under four different feeding rate $(20,30,40$ and $50 \mathrm{~kg} / \mathrm{min})$, five drum speeds 3.25 , $5.47,6.98,8.52$ and $10.64 \mathrm{~m} / \mathrm{s}(345,580,740,903$ and $1130 \mathrm{rpm}$ respectively) and four time spans after harvest (0,3, 6 and 9 days) and the measurements were cleaning efficiency, extraction efficiency, machine productivity, visible seed damage, consumed power and operating cost.

\subsubsection{Cleaning efficiency, \%:}

The cleaned seeds $\left(\mathrm{M}_{\mathrm{c}}\right)$ were collected from the outlets seed opening and weighed. Also, seeds which expelled $\left(\mathrm{M}_{\mathrm{L})}\right.$ with peels and foreign matters were picked and weighed. The cleaning efficiency was calculated according the following equation:

$$
\text { Cleaning efficiency, } \%=\frac{M_{c}}{M_{c}+M_{1}} \times 100
$$

\subsubsection{Extraction efficiency, \%:}

Extraction efficiency of seed extraction machine was calculated according to the following equation:

$$
\text { Extraction efficiency, } \%=\frac{M_{2}}{M_{1}+M_{2}} \times 100
$$

Where: $M_{1}$ is the mass of collected seeds, $g$ and $M_{2}$ is mass of seeds expelled out of the machine. 


\subsubsection{Machine productivity of seeds, $\mathrm{kg} / \mathrm{h}$ :}

Seed productivity of the manufactured machine was determined by operating machine at different drum speeds and different feeding rates. The amount of seeds, which were received from outlet opening, was weighed at different intervals from harvesting time. The experiment was repeated three times and the mean mass of seeds was estimated. Extraction capacity was calculated according to the following equation:

$$
\mathrm{C}=\frac{60 \times \mathrm{M}}{\mathrm{T}_{\mathrm{s}}}
$$

Where: $\mathrm{C}$ is the machine productivity of seeds, $\mathrm{kg} / \mathrm{h}, \mathrm{M}$ is mass of melon seed, $\mathrm{kg}$, and $\mathrm{T}_{\mathrm{s}}$ is machine operating time, min.

\subsubsection{Visible seeds damage:}

Visible seed damage was determined by extracting damaged seeds by hand from a mass of 50 grams sample, which was taken by a randomized method from the extracted seeds. The percentage of Visible seed damage was calculated based on the original weight of sample and it was calculated according to Desta and Mishra (1990) as follows:

$$
\text { Visible seed damage, } \%=\frac{\mathrm{M}_{\mathrm{b}}}{\mathrm{M}_{\mathrm{t}}} \times 100
$$

Where: $M_{b}$ is mass of broken seeds in each sample, $g$, and $M_{t}$ is the total mass of seeds in same sample, g.

\subsubsection{Fuel and Power requirement:}

A measured volume of fuel was put into the fuel tank of the extraction prototype before operating it in the field for a specific period. After the work was over, the volume left in fuel tank was measured using a measure jar, from these observations. The volume of fuel consumed was determined and the rate of fuel consumption was calculated according to Rangasamy et al. (1993) as follow,

$$
\text { F. C. }=\frac{\text { c.f. }}{1000} \times \frac{60}{\mathrm{~T}}
$$

Where: F.C is the rate of fuel consumption, $1 / \mathrm{h}$, f.c. is the consumed amount of fuel, $\mathrm{ml}$ and $\mathrm{T}$ is the time of operation, $\min$.

The total power consumed by the extraction prototype was calculated by using the measured fuel consumption during extracting operation Power 
required (PR) was calculated by the following formula (Barger et al., 1963).

$$
\text { PR }=\text { F.C } \times \frac{1}{3600} \rho f \times L . C . V \times 427 \times \frac{1}{75} \times \frac{1}{1.36} \times \eta_{t h} \times \eta_{m}
$$

Where: F.C.is the fuel consumption $(1 / h), \rho f$ is the density of fuel $(0.85$ $\mathrm{kg} / \mathrm{l}$.), L.C.V. is lower calorific value of solar fuel (Average 10000 $\mathrm{kcal} / \mathrm{kg}), 427$ is the thermo mechanical equivalent, $(\mathrm{kg} . \mathrm{m} / \mathrm{kcal}), \eta_{\text {th }}$ is the thermal efficiency of the engine (35\% for diesel engine) and $\eta_{\mathrm{m}}$ is the mechanical efficiency of the engine ( $80 \%$ for diesel engine).

\subsubsection{Cost analysis}

Machinery costs, which include fixed costs (depreciation, interest, housing, insurance and taxes) and variable costs that include (repair and maintenance, fuel, oil and labor) are the major capital input along with the operational and labour cost to determine the total extraction cost. Cost details are presented in Table 3.

Table 3: Details of cost calculation for seed extraction prototype:

\begin{tabular}{|l|c|c|}
\multirow{2}{*}{ Item } & \multicolumn{2}{|c|}{ Cost, LE/h } \\
\cline { 2 - 3 } & Tractor & Machine \\
\hline Manufacture price, LE & 40000 & 8000 \\
A-Fixed cost & & \\
$\quad$ Interest on investment, LE/h & 0.572 & 0.715 \\
depreciation, LE/h & 3.6 & 4.5 \\
Annual taxes, insurance and housing, LE/h & 0.08 & 0.1 \\
\hline B-Variable costs & & \\
Repair and maintenance, LE/h & 4.25 & 2.65 \\
Fuel cost(max) LE/h & 3.88 & +++ \\
Oil, grease and lubricant, LE/h & 0.58 & +++ \\
$\quad$ Labor cost (2 labor and driver), LE/h & 6.25 & 12.5 \\
\hline Total fixed cost, LE/h & 4.25 & 5.32 \\
\hline Variable costs, LE/h & 14.97 & 15.15 \\
\hline Total cost, LE/h & 19.22 & 20.47 \\
\hline
\end{tabular}

To estimate the total production/operation cost $(\mathrm{LE} / \mathrm{kg}$, total costs $(\mathrm{LE} / \mathrm{h})$ was divided by machine productivity $(\mathrm{kg} / \mathrm{h})$ as below equation:

$$
\text { Operation cost }=\frac{\text { Total cost, } \mathrm{LE} / \mathrm{h}}{\text { Machine productivity, } \mathrm{kg} / \mathrm{h}}, \mathrm{LE} / \mathrm{kg}
$$




\subsubsection{Statistical analysis:}

Experimental design of split-split plots was followed in current study with 3 replications. Experimental data were analyzed statistically and analysis of variance (ANOVA) and standard deviation (S.D.) were generated at critical difference of 5\% level by using XLSTAT package.

\section{RESULTS AND DISCUSSION}

\subsection{Cleaning efficiency, \%:}

Figure 7 illustrates the effect of melon seed time span, melon seed feed rate, crushing drum speed on cleaning efficiency. The results showed that, increase crushing drum speed from 3.25 to $10.64 \mathrm{~m} / \mathrm{s}$ tended to increase cleaning efficiency from 78.13 to $79.51 \%$ and from 82.11 to $83.94 \%$ and from 85.16 to $86.53 \%$ and from 87.11 to $88.83 \%$ at melon seed time span of $0,3,6$ and 9 days respectively and melon seed feed rate of $20 \mathrm{~kg} / \mathrm{min}$. In the same manner, the increase of melon seed feed rate from 20 to $50 \mathrm{~kg} / \mathrm{min}$ lead to decreasing cleaning efficiency from 78.13 to $74 \%$ and from 82.11 to $77.12 \%$ and from 85.16 to $81.23 \%$ and from 87.11 to $83.87 \%$ for melon seed time span of $0,3,6$ and 9 days respectively and crushing drum speed of $3.25 \mathrm{~m} / \mathrm{s}$. Also, results indicated that by increasing melon seed time span from 0 to 9 day, cleaning efficiency increased from 78.13 to $87.11 \%$ at feed rate of $20 \mathrm{~kg} / \mathrm{min}$ and crushing drum speed $3.25 \mathrm{~m} / \mathrm{s}$. The maximum value of cleaning efficiency was $88.83 \%$ at crushing drum speed of $10.64 \mathrm{~m} / \mathrm{s}$, melon seed feed rate of $20 \mathrm{~kg} / \mathrm{min}$ and melon seed time span of 9 day. However, minimum value of $74.00 \%$ was recorded at crushing drum speed of 3.25 $\mathrm{m} / \mathrm{s}$, melon seed feed rate of $50 \mathrm{~kg} / \mathrm{min}$ and melon seed time span of 0 day. Modeling data by using analysis of variance (ANOVA) showed that the melon seed feed rate and time span of melon seed had highly significant effects on cleaning efficiency. However, drum speed and replication had no significant effect on cleaning efficiency and the standard deviation (S.D.) was 4.639.

\subsection{Extraction efficiency, \%:}

Figure 8 illustrates effect of melon seed time span, melon seed feed rate, crushing drum speed on extraction efficiency. The results showed that, increase crushing drum speed from 3.25 to $10.64 \mathrm{~m} / \mathrm{s}$ tended to decrease extraction efficiency from 96.41 to $94.98 \%$ and from 69.89 to $95.9 \%$ 
and from 97.87 to $97.32 \%$ and from 98.85 to $98.26 \%$ for melon seed time span of 0, 3, 6 and 9 day respectively and melon seed feed rate of 20 $\mathrm{kg} / \mathrm{min}$. In the same manner, the increase of melon seed feed rate from 20 to $50 \mathrm{~kg} / \mathrm{min}$ lead to decreasing extraction efficiency from 96.41 to $93.04 \%$ and from 96.89 to $93.89 \%$ and from 97.87 to $95.83 \%$ and from 98.85 to $96.46 \%$ for melon seed time span of $0,3,6$ and 9 day, respectively and crushing drum speed of $3.25 \mathrm{~m} / \mathrm{s}$. Also, results indicated that by increase melon seed time span from 0 to 9 day, extraction efficiency increased from 96.11 to $98.85 \%$ at feed rate of $20 \mathrm{~kg} / \mathrm{min}$ and crushing drum speed $3.25 \mathrm{~m} / \mathrm{s}$. The maximum value of extraction efficiency was $98.85 \%$ at crushing drum speed of $3.25 \mathrm{~m} / \mathrm{s}$, melon seed feed rate of $20 \mathrm{~kg} / \mathrm{min}$ and melon seed time span of 9 day. While, the minimum value of $92.44 \%$ was recorded at crushing drum speed of $10.64 \mathrm{~m} / \mathrm{s}$, melon seed feed rate of $50 \mathrm{~kg} / \mathrm{min}$ and melon seed time span of 0 day. The statistical analysis cleared that time span of melon seed, melon seed feed rate had highly significant effects on extraction efficiency with standard deviation (S.D.) 1.996.
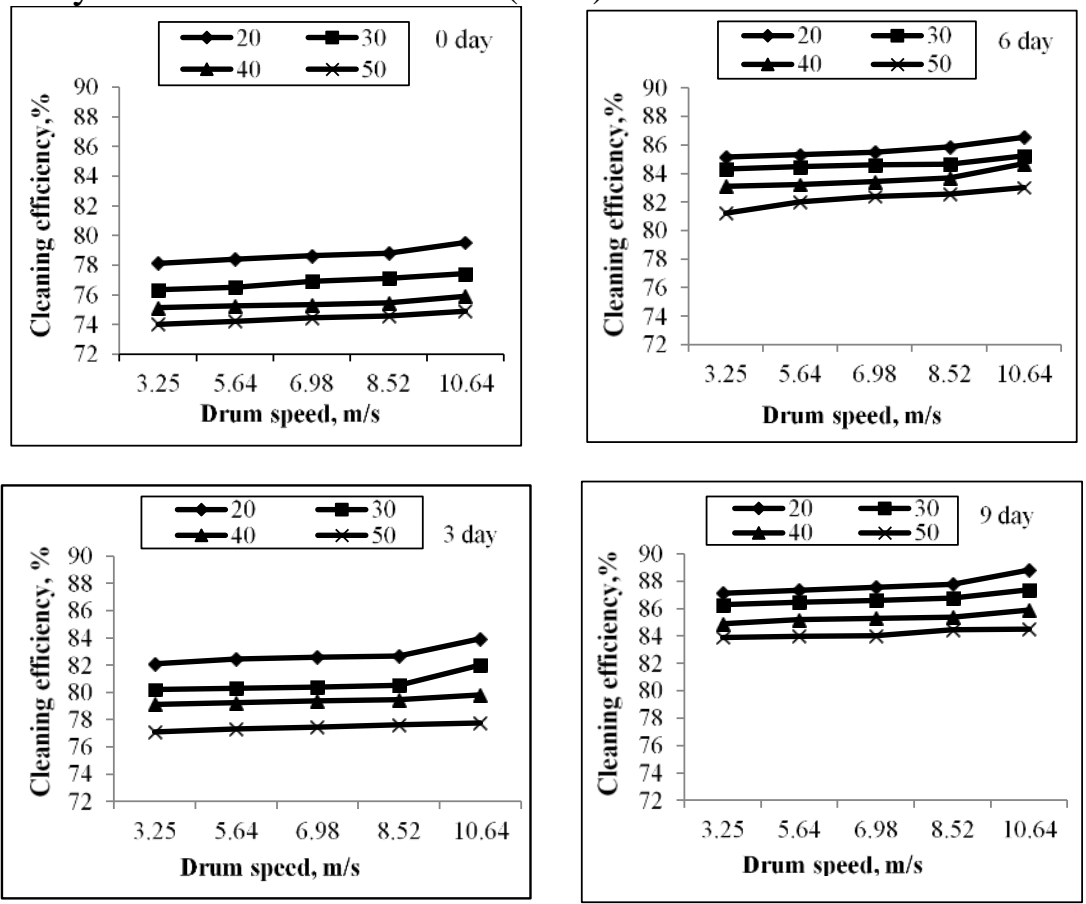

Figure 7: Effect of drum speed, feed rate and time span on cleaning efficiency of melon seed. 

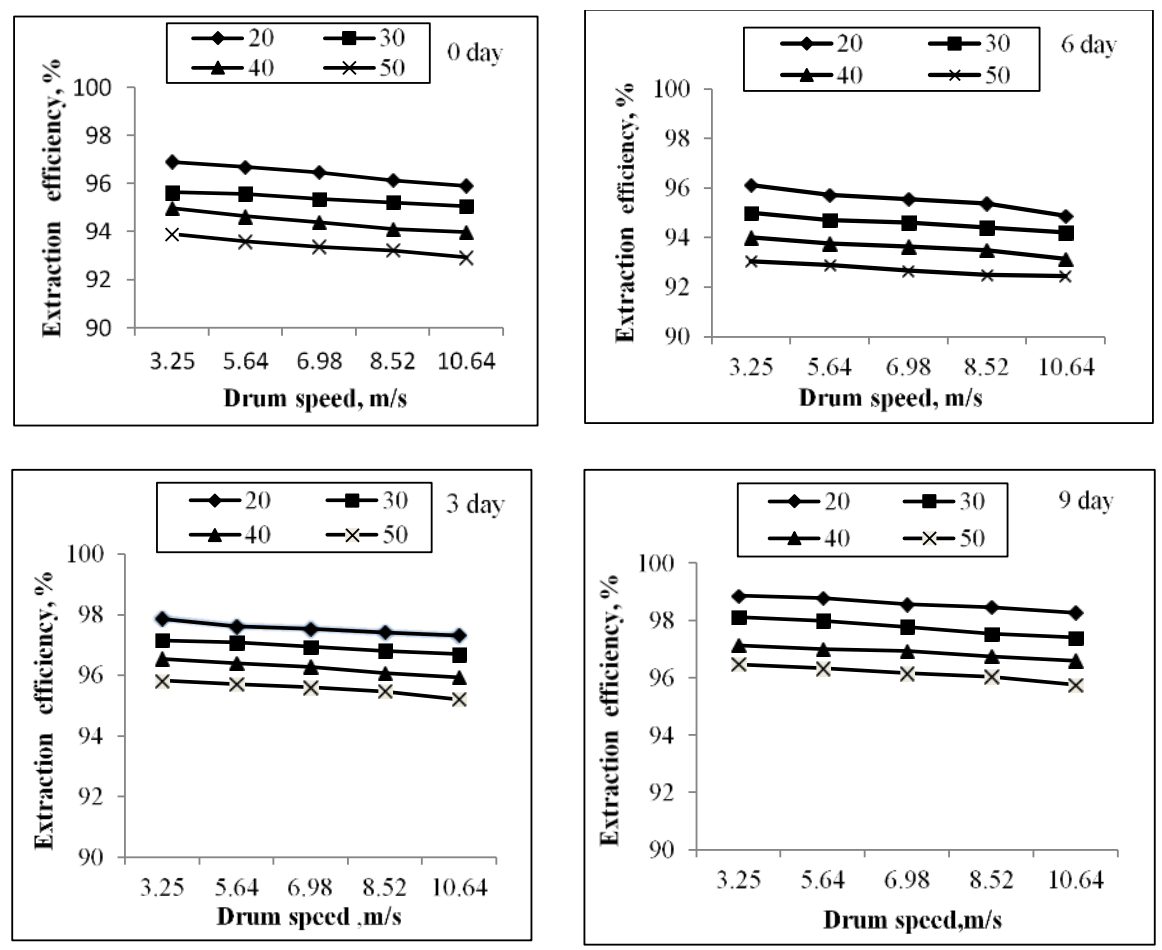

Figure 8: Effect of drum speed, feed rate and time span on extraction efficiency of melon seed.

\subsection{Machine productivity:}

Figure 9 illustrates effect of melon seed time span, melon seed feed rate, crushing drum speed on machine productivity. The results indicated that by increasing crushing drum speed from. 3.25 to $10.64 \mathrm{~m} / \mathrm{s}$, machine productivity decreased from 57.16 to $49.36 \mathrm{~kg} / \mathrm{h}$ and from 59.11 to 52.79 $\mathrm{kg} / \mathrm{h}$ and from 62.07 to $54.38 \mathrm{~kg} / \mathrm{h}$ and from 63.37 to $54.97 \mathrm{~kg} / \mathrm{h}$ for melon seed time span 0, 3, 6 and 9 day respectively and melon seed feed rate of $20 \mathrm{~kg} / \mathrm{min}$. The reason for that may be due to excess the amount of seeds discharged with pulp and accordingly the machine productivity will be lower.

In the same manner, the increase of melon seed feed rate from 20 to 50 $\mathrm{kg} / \mathrm{min}$ lead to increase machine productivity from 57.16 to $141.72 \mathrm{~kg} / \mathrm{h}$ and from 59.11 to $146.01 \mathrm{~kg} / \mathrm{h}$ and from 62.07 to $149.64 \mathrm{~kg} / \mathrm{h}$ and from 63.37 to $152.14 \mathrm{~kg} / \mathrm{h}$ at crushing drum speed of $3.25 \mathrm{~m} / \mathrm{s}$ and melon seed time span of $0,3,6$ and 9 day respectively. Also, increasing feed rates lead to increase machine productivity; this may be due to increase the 
amount seed discharged per unit time. The results also, showed that increase melon seed time span from 0 to 9 day at melon seed feed rate of $20 \mathrm{~kg} / \mathrm{min}$ and crushing drum speed of $3.25 \mathrm{~m} / \mathrm{s}$ lead to increase machine productivity from 57.16 to $63.37 \mathrm{~kg} / \mathrm{h}$, this declare that melon seed time span is helpful variable to extract seeds from the pulp and consequently, increase amount of seeds discharged from machine outlets and increasing machine productivity. The maximum value of machine productivity was $152.14 \mathrm{~kg} / \mathrm{h}$ at crushing drum speed of $3.25 \mathrm{~m} / \mathrm{s}$, feed rate of $50 \mathrm{~kg} / \mathrm{h}$ and melon seed time span of 9 day. While, the minimum value of machine productivity was $49.36 \mathrm{~kg} / \mathrm{h}$ at crushing drum speed of $10.64 \mathrm{~m} / \mathrm{s}$, melon seed feed rate of $20 \mathrm{~kg} / \mathrm{min}$ and melon seed time span of 0 day. Modeling data by using analysis of variance (ANOVA) showed that crushing drum speed, melon seed feed rate and melon seed time span had highly significant effects on machine productivity, while replications had no significant effects and the standard deviation (S.D.) was 32.555 .
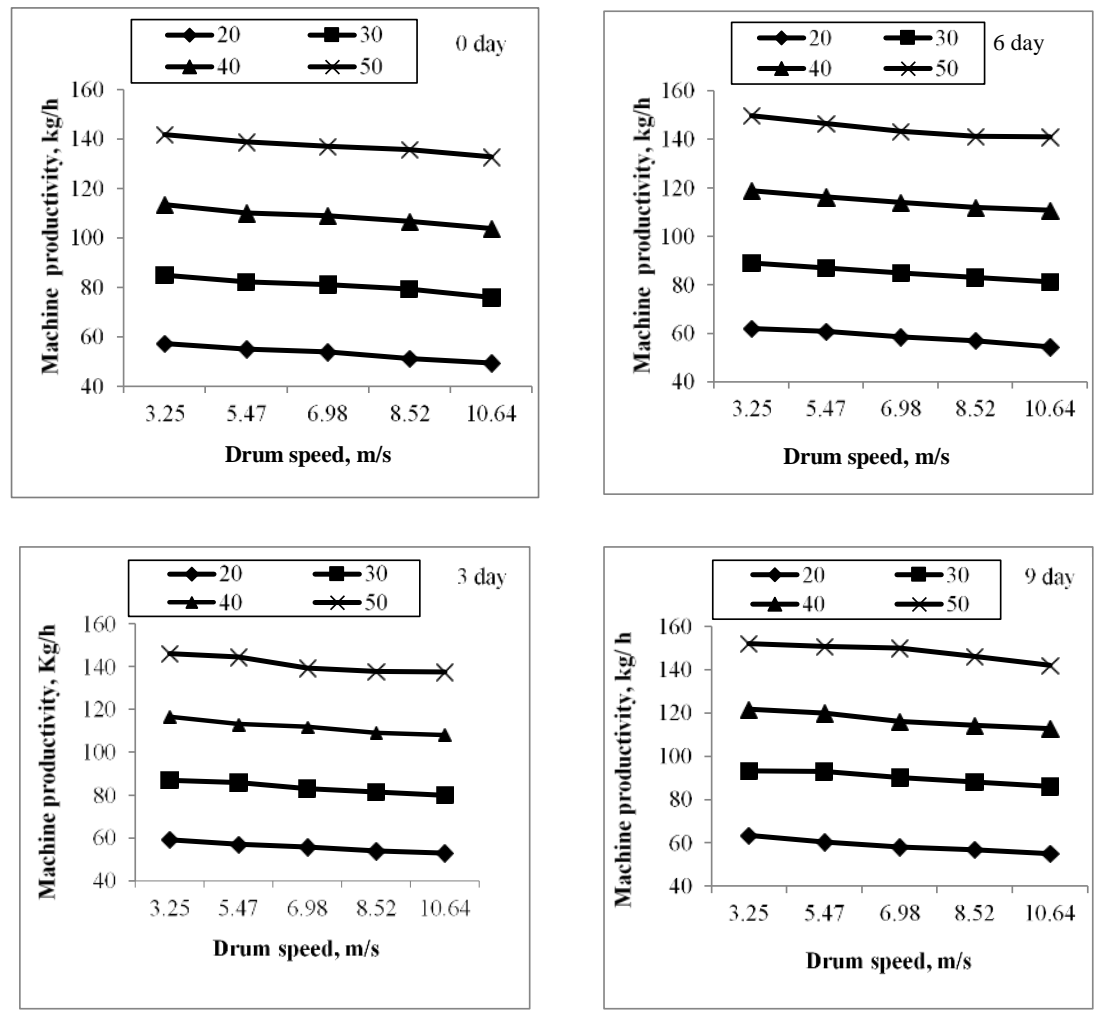

Figure 9: Effect of drum speed, feed rate and time span on machine productivity of melon seed. 


\subsection{Power consumption, $\mathrm{kW}$ :}

Figure 10 illustrates the effect of melon seed time span, melon seed feed rate, crushing drum speed on power consumed. Results showed that, increase crushing drum speed from 3.25 to $10.64 \mathrm{~m} / \mathrm{s}$ tended to increase the power consumed from 2.35 to $4.59 \mathrm{~kW}$ and from 2.13 to $4.28 \mathrm{~kW}$ and from 1.83 to $3.93 \mathrm{~kW}$ and from 1.53 to $3.68 \mathrm{~kW}$ for melon seed time span of $0,3,6$ and 9 day respectively, and feed rate of $20 \mathrm{~kg} / \mathrm{min}$. The results also, indicated that the increase of melon seed feed rate from 20 to $50 \mathrm{~kg} / \mathrm{min}$ lead to increasing the power consumed from 2.35 to $3.90 \mathrm{~kW}$ and from 2.13 to $3.59 \mathrm{~kW}$ and from 1.83 to $3.40 \mathrm{~kW}$ and from 1.53 to $2.99 \mathrm{~kW}$ for melon seed time span from $0,3,6$ to 9 day, respectively at crushing drum speed $3.25 \mathrm{~m} / \mathrm{s}$. The results showed that by increased melon seed time span from 0 to 9 day, the power consumed decreased from 2.35 to $1.53 \mathrm{~kW}$ at feed rate of $20 \mathrm{~kg} / \mathrm{min}$ and crushing drum speed of $3.25 \mathrm{~m} / \mathrm{s}$. The maximum value of power consumed was $5.98 \mathrm{~kW}$ at crushing drum speed of $10.64 \mathrm{~m} / \mathrm{s}$, melon seed feed rate of $50 \mathrm{~kg} / \mathrm{min}$ and melon seed time span of 0 day. While, the minimum value of power consumed was $1.53 \mathrm{~kW}$ at crushing drum speed of $3.25 \mathrm{~m} / \mathrm{s}$, melon seed feed rate of $20 \mathrm{~kg} / \mathrm{min}$ and melon seed time span of 9 day. Modeling data by using analysis of variance (ANOVA) showed that crushing drum speed, melon seed feed rate and melon seed time span had highly significant effects on power consumed where replications had no significant effects with standard deviation (S.D.) 0.974.

\subsection{Visible seed damage, $\%$ :}

Figure 11 illustrates the effect of melon seed time span, melon seed feed rate and crushing drum speed on visible seed damage. The results showed that increasing crushing drum speed from 3.25 to $10.64 \mathrm{~m} / \mathrm{s}$ tended to increase visible seed damage from 4.71 to $5.22 \%, 4.62$ and from $5.01 \%, 3.99$ to $4.39 \%$ and from 3.44 to $3.82 \%$ for melon seed time span of $0,3,6$ and 9 day, respectively, and feed rate of $20 \mathrm{~kg} / \mathrm{min}$. The results also, indicated that the increase of melon seed feed rate from 20 to $50 \mathrm{~kg} / \mathrm{min}$ leads to decreasing visible seed damage from 4.71 to $3.18 \%$ and from 4.62 to $2.71 \%$ and from 3.99 to $2.61 \%$ and from 3.44 to $1.56 \%$ for melon seed time span from $0,3,6$ to 9 day respectively and crushing drum speed of $3.25 \mathrm{~m} / \mathrm{s}$. 

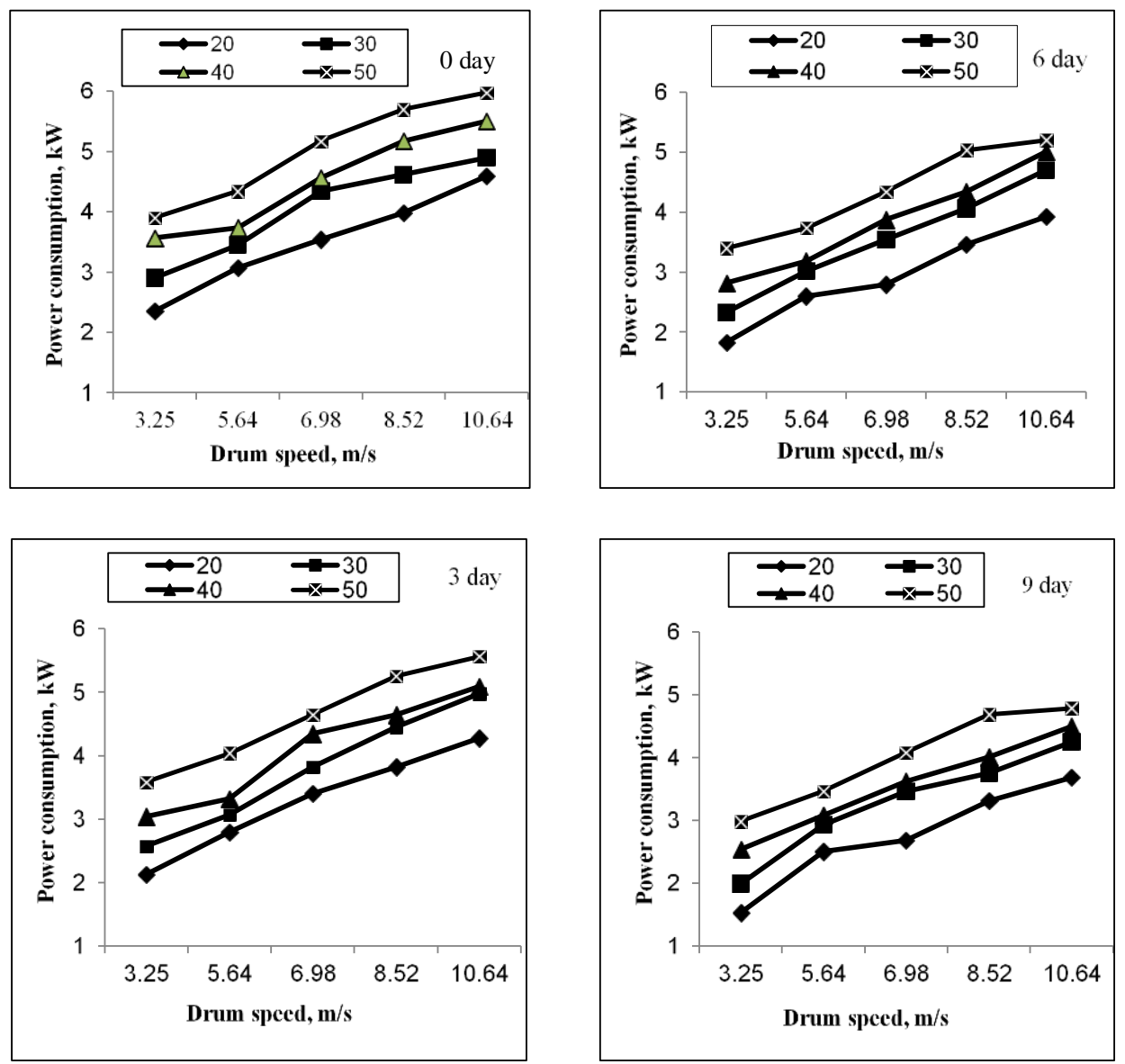

Figure 10: Effect of drum speed, feed rate and time span on power consumption of melon seed.

Also, the increase in melon seed time span from 0 to 9 day, visible seed damage decreased from 4.71 .6 to $3.44 \%$ at feed rate of $20 \mathrm{~kg} / \mathrm{min}$ and crushing drum speed of $3.25 \mathrm{~m} / \mathrm{s}$. The maximum value of visible seed damage was $5.22 \%$ at crushing drum speed of $10.64 \mathrm{~m} / \mathrm{s}$, melon seed feed rate of $20 \mathrm{~kg} / \mathrm{min}$ and melon seed time span 0 day. While, minimum value of visible seed damage was $1.55 \%$ at crushing drum speed of 3.25 $\mathrm{m} / \mathrm{s}$, melon seed feed rate of $50 \mathrm{~kg} / \mathrm{min}$ and melon seed time span 9 day. The statistical analysis cleared that crushing drum speed, melon seed feed rate and melon seed time span, had highly significant effects on power consumed with standard deviation 0.856 . 

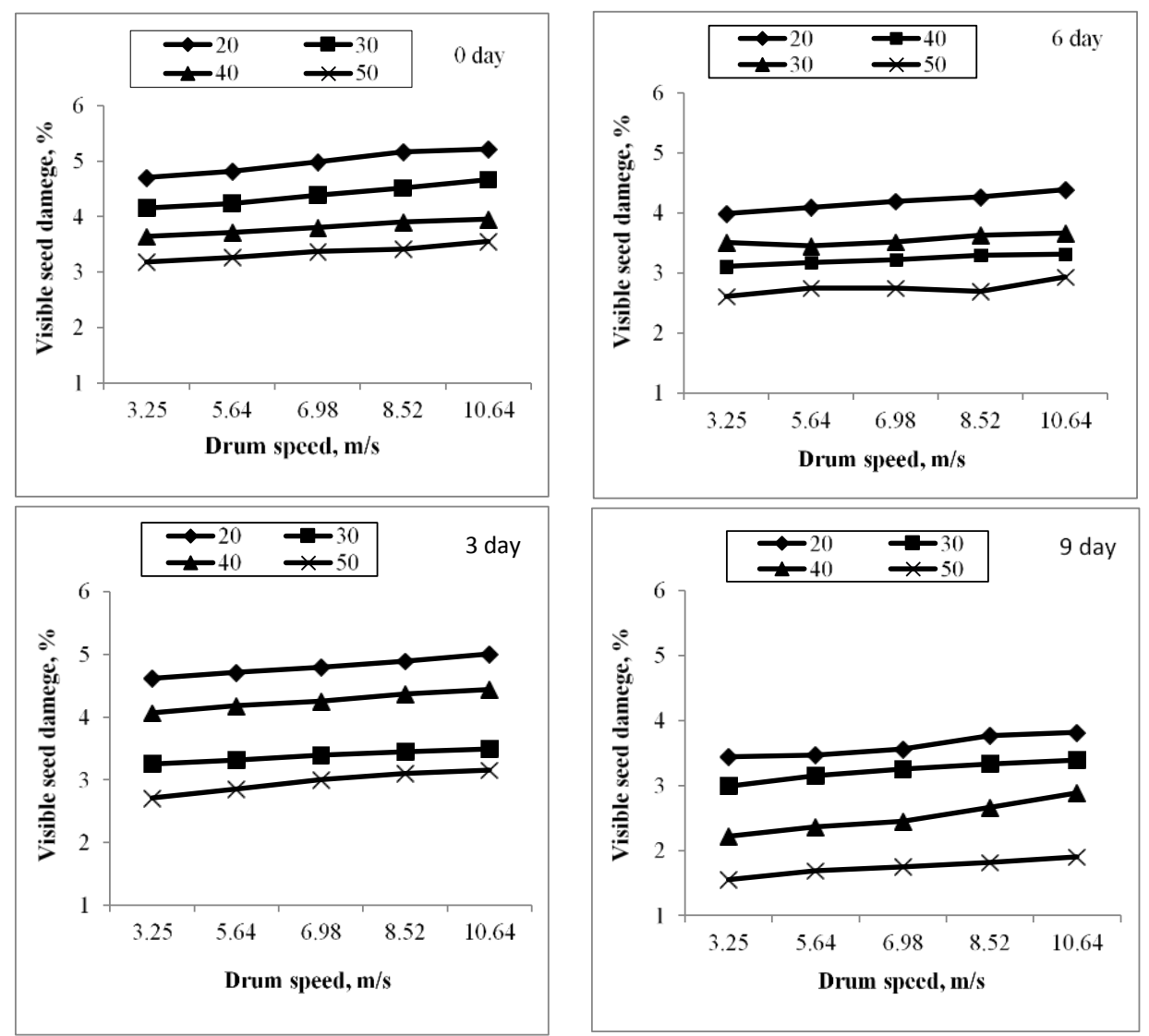

Figure 11: Effect of drum speed, feed rate and time span on seed damage of melon seed.

\subsection{Total cost, LE/kg:}

Table 4 shows the effect of crushing drum speed, melon seed time span on total cost. From the economics point of view, the use of any machine usually depends on machine purchase price, labor charges, working capacity of machine and other factors. The results indicated that the total fixed cost is $9.57 \mathrm{LE} / \mathrm{h}$ for the prototype and tractor together. The results also, showed that increasing crushing drum speed from 3.25 to $10.64 \mathrm{~m} / \mathrm{s}$ tended to increase the total cost from 0.718 to $0.886 \mathrm{LE} / \mathrm{kg}$, and from 0.692 to $0.805 \mathrm{LE} / \mathrm{kg}$ and from 0.655 to $0.777 \mathrm{LE} / \mathrm{kg}$ and from 0.638 to $0.765 \mathrm{LE} / \mathrm{kg}$ for melon seed time span of $0,3,6$ and 9 day respectively, and feed rate of $20 \mathrm{~kg} / \mathrm{min}$. The result also indicated that increase melon seed feed rate from 20 to $50 \mathrm{~kg} / \mathrm{min}$ lead to decrease the total cost from 0.718 to $0.298 \mathrm{LE} / \mathrm{kg}$ and from 0.692 to $0.288 \mathrm{LE} / \mathrm{kg}$ and from 0.655 to 
$0.280 \mathrm{LE} / \mathrm{kg}$ and from 0.638 to $0.273 \mathrm{LE} / \mathrm{kg}$ for melon seed time span from $0,3,6$ to 9 day respectively and crushing drum speed of $3.25 \mathrm{~m} / \mathrm{s}$. By increasing melon seed time span from 0 to 9 day, the total cost decreased from 0.718 to $0.638 \mathrm{LE} / \mathrm{kg}$ at feed rate of $20 \mathrm{~kg} / \mathrm{min}$ and crushing drum speed of $3.25 \mathrm{~m} / \mathrm{s}$. The maximum value of total cost was $0.866 \mathrm{LE} / \mathrm{kg}$ at crushing drum speed of $10.64 \mathrm{~m} / \mathrm{s}$, melon seed feed rate of $20 \mathrm{~kg} / \mathrm{min}$ and melon seed time span 0 day. While, the minimum value of total cost was $0.273 \mathrm{LE} / \mathrm{kg}$ at crushing drum speed of $3.25 \mathrm{~m} / \mathrm{s}$, melon seed feed rate of $50 \mathrm{~kg} / \mathrm{min}$ and 9 day of melon seed time span.

Table 4: Effect of drum speed, feed rate and time span of melon seed on total cost, $\mathrm{LE} / \mathrm{kg}$.

\begin{tabular}{|c|c|c|c|c|c|c|}
\hline \multirow{3}{*}{$\begin{array}{l}\text { Time } \\
\text { span } \\
\text { Day }\end{array}$} & \multirow{3}{*}{$\begin{array}{c}\text { Feed } \\
\text { rate, } \\
\text { kg/min }\end{array}$} & \multicolumn{5}{|c|}{ Cost, LE/kg } \\
\hline & & \multicolumn{5}{|c|}{ Drum speed, $\mathrm{m} / \mathrm{s}$} \\
\hline & & 3.25 & 5.47 & 6.98 & 8.52 & 10.64 \\
\hline \multirow{4}{*}{0} & 20 & 0.718 & 0.755 & 0.779 & 0.825 & 0.866 \\
\hline & 30 & 0.488 & 0.510 & 0.525 & 0.539 & 0.565 \\
\hline & 40 & 0.370 & 0.382 & 0.393 & 0.404 & 0.418 \\
\hline & 50 & 0.298 & 0.306 & 0.315 & 0.321 & 0.330 \\
\hline \multirow{4}{*}{3} & 20 & 0.692 & 0.724 & 0.750 & 0.780 & 0.805 \\
\hline & 30 & 0.474 & 0.484 & 0.507 & 0.524 & 0.538 \\
\hline & 40 & 0.356 & 0.369 & 0.381 & 0.392 & 0.399 \\
\hline & 50 & 0.288 & 0.293 & 0.307 & 0.314 & 0.316 \\
\hline \multirow{4}{*}{6} & 20 & 0.655 & 0.678 & 0.708 & 0.736 & 0.777 \\
\hline & 30 & 0.460 & 0.478 & 0.494 & 0.510 & 0.528 \\
\hline & 40 & 0.348 & 0.359 & 0.370 & 0.380 & 0.389 \\
\hline & 50 & 0.280 & 0.287 & 0.297 & 0.305 & 0.307 \\
\hline \multirow{4}{*}{9} & 20 & 0.638 & 0.681 & 0.711 & 0.736 & 0.765 \\
\hline & 30 & 0.437 & 0.447 & 0.465 & 0.478 & 0.494 \\
\hline & 40 & 0.339 & 0.347 & 0.362 & 0.370 & 0.378 \\
\hline & 50 & 0.273 & 0.278 & 0.282 & 0.293 & 0.302 \\
\hline
\end{tabular}


A multiple regression analysis was made taking cleaning efficiency $\left(\eta_{c}\right)$, extraction efficiency $\left(\eta_{\mathrm{e}}\right)$, machine productivity $\left(\mathrm{M}_{\mathrm{p}}\right)$, seed damage $\left(\mathrm{S}_{\mathrm{d}}\right)$, and power consumption $\left(\mathrm{P}_{\mathrm{c}}\right)$, as dependent variables and time span of melon seed, melon seed feed rate and crushing drum speed as independent variables. The regression equation obtained was as follows:

$$
\mathrm{Y}=\mathrm{a}_{0}+\mathrm{b}_{2} \text { F.R }+\mathrm{b}_{3} \mathrm{G} . \mathrm{S}
$$

Where: $\mathrm{Y}$ is the dependent variable, T.S is the time span, day, $(0 \leq \mathrm{TS} \leq$ 9), F.R. is melon seed feed rate, $\mathrm{kg} / \mathrm{min},(20 \leq \mathrm{F} . \mathrm{R} \leq 50)$, G.S is crushing drum speed, $\mathrm{m} / \mathrm{s},(8.62 \leq \mathrm{S} \leq 10.99), \mathrm{a}_{0}$ is the constant, and, $\mathrm{a}_{1}, \mathrm{~b}_{2}$ and $\mathrm{b}_{3}$ are regression coefficients. The values of regression coefficients and $R^{2}$ are given in Table 5 .

The values constants for the extraction machine under a given conditions and units used and such equation enables the predicting of the extraction performance of machine for different values of time span, melon seed feed rate and crushing drum speed in the range mentioned above.

Table 5: Multiple regression coefficients for the output parameters of the extraction machine during experiments.

\begin{tabular}{|c|c|c|c|c|c|}
\hline \multirow{2}{*}{ Dependent variable (Y) } & \multirow{2}{*}{$\mathrm{a}_{0} *$} & \multicolumn{3}{|c|}{ Regression coefficients } & \multirow{2}{*}{$\mathrm{R}^{2}$} \\
\cline { 3 - 5 } & & $\mathrm{b}_{1}$ & $\mathrm{~b}_{2}$ & $\mathrm{~b}_{3}$ & \\
\hline Cleaning efficiency & 80.180 & 1.08 & -0.112 & -0.085 & 0.697 \\
\hline Extraction efficiency & 97.660 & 0.330 & -0.087 & -0.075 & 0.972 \\
\hline Machine productivity & 2.320 & 0.980 & 2.680 & -1.150 & 0.993 \\
\hline Power consumption & 0.635 & -0.970 & 0.044 & 0.029 & 0.960 \\
\hline Seed damage & 5.640 & -0.950 & -0.056 & -0.520 & 0.820 \\
\hline
\end{tabular}

$\mathrm{a}_{0}=$ constant

$a_{1}, b_{2}$ and $b_{3}=$ regression coefficients

\section{CONCLUSION}

A local seeds extraction prototype was manufactured and evaluated at different machine operational conditions, including four different feeding rates $(20,30,40$, and $50 \mathrm{~kg} / \mathrm{min})$, five crushing speeds $(3.25,5.47,6.98$, 
8.52, and $10.64 \mathrm{~m} / \mathrm{s})$ and time span (0,3, 6, and 9 days). The results showed that crushing drum speed of $10.64 \mathrm{~m} / \mathrm{s}$, feed rate of $20 \mathrm{~kg} / \mathrm{min}$ and time span of 9 day gave the best cleaning efficiency of $88.83 \%$. While, using the prototype at crushing drum speed of $3.25 \mathrm{~m} / \mathrm{s}$, feed rate of $20 \mathrm{~kg} / \mathrm{min}$ and time span of 9 day, gave the best extraction efficiency of $98.85 \%$. The results indicated that crushing drum speed of $3.25 \mathrm{~m} / \mathrm{s}$, feed rate of $50 \mathrm{~kg} / \mathrm{min}$ and time span of 9 day gave best machine productivity of $152.14 \mathrm{~kg} / \mathrm{h}$. Meanwhile, at crushing drum speed of 3.25 $\mathrm{m} / \mathrm{s}$, feed rate of $20 \mathrm{~kg} / \mathrm{min}$ and time span of 9 day lowest power consumed of $2.61 \mathrm{~kW}$ was obtained. The results showed that using the prototype with crushing drum speed of $3.25 \mathrm{~m} / \mathrm{s}$, feed rate of $50 \mathrm{~kg} / \mathrm{min}$ and time span of 9 day gave lowest seed damage of $1.53 \%$ and total cost of $0.273 \mathrm{LE} / \mathrm{kg}$. With looking to the cost and time consumed in manual processes from previous studies, the developed prototype can save the extraction cost and time by 40 and $50 \%$ respectively compared to the manual extraction method also decrease seed losses and seed damage.

\section{REFERENCES}

Abd El-Mageed, H.N. and H.E. Abd All (1994). A simple machine for grading fresh tomatoes. J. Agric. Sci., Mansoura Univ., 19(9): 3033-3047.

Abdrabo, A.F.A (2014). Manufactured prototype to separate the seeds of melon pulp Egypt. J. Agric. Res., 92 (1)237:255.

Abou-Elmagd, A.E., H.N Abd El-Mageed, M.A. Baiomey and I.F. Sayed-Ahmed (2006). Proper design and evaluation of equipment for extracting melon seed, J. Agric Sci. Mansoura Univ., 31(7): 5368.

Amir, I.F.S (2004). Construction and performance of machine for separating watermelon seed. Ph.D. Thesis., Fac. Of Agric Mansoura, Univ., Egypt. Unpublished.

Awady, M.N. and A.S. (1994). Separation of peanut by airstream Misr J. Ag. Eng.,11(1): 137-147. 
Barger, E.L., J.B.L. Edohi, W.M. Carletor and E.G. Mchibben (1963). Tractor and their power units. $2^{\text {nd }}$ Ed., Wiley. Sons Inc, New Yourk, USA.

Desta, K.D. and T.W. Mishra (1990). Development and performance evaluation of Sorghum thresher. AMA, 21(3): 33-37.

Dutta, S.K.; V.K. Nema and R.K. Bhardwaj (1988). Physical properties of grain. J. Agric. Eng. Res., 39: 259-268.

Egbe, D.E., E.G. Ebot, T.S. Mayah, P.A. Egbe and J.P. Abraham (2015). Performance Evaluation and Improvement Melon Seed Shelling Machine. World Journal of Agricultural Sciences \&Engineering 1(1):1 -10 .

Eliwa, A.A and A. Elfatih (2012). Developing a local extraction melon seed machine. Journal of Applied Sciences Research, 8(1): 474482.

Ministry of Agriculture (2012). Agricultural statistics, Economic Issues sector, Cairo, Egypt: 78-115.

Oloko, S.A. and L.A.S. Agbetoye (2006). Development and Performance Evaluation of a Melon Depodding Machine. Agricultural Engineering International. The CIGR Ejournal. Manuscript. PMD 6018 Vol. vii.

Rangasamy, K., M. Balasubramanian and K.R. Swaminathan (1993). Evaluation of power weeder performance. AMA, 24(4): 16-18.

Shreen, F.A.M. (2014). Development and evaluation of a local industrial machine for watermelon on seeds extraction. J. Soil Sci. and Agric. Eng., Mansoura Univ. 5(10): 1405-1426.

Sobowale S.S., J.A. Adebiyi and O.A Adebo (2015). Design, Construction and Performance Evaluation of a Melon Seeds Sheller. J. Food Process Technol. 6: 463. 
Tayel, S.A., A.A. EL-Nakib, M.F. Akhairy and D.M. Desiuky (2010). Factors affecting Cucurbita-pepo crop seed losses and damage by using a seed extracting machine prototype. Misr j. Ag., 27(3): 824838.

Yehia, I., M.H. Kabeel and M.M. Abdel Galeel (2009). Physical an mechanical properties of Ponkan mandarin applied to grading machine, Misr J. Ag. Eng. 26(2): 1036-1053.

\section{المخلص العربيى}

\section{تصنيع وتقيم نموذج اولي لآلة فصل بذور بطيخ اللب}

محمد نعمة الله' رزق خليف؟ رشاد حجازى" اسماعيل عبد المطلب؛

تعتبر عملية ميكنة إنتاج محصول بطيخ اللب من الوسائل التي تساهم في زيادة جودته ومن ثم

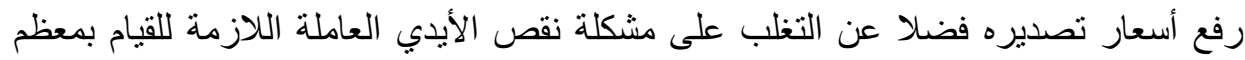

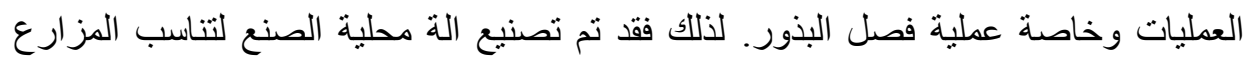

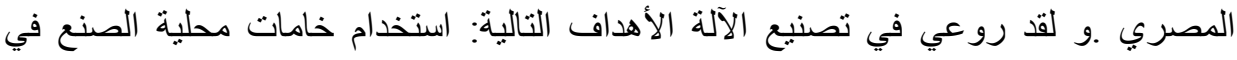

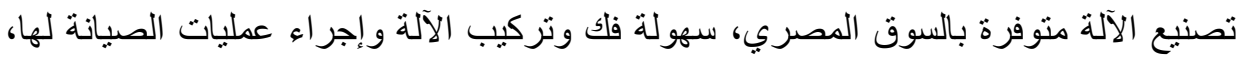
تقليل الطاقة المستهكة وتقليل التكاليف الكلية مما بشجع علي التهني التخدامها، أن تعمل الآلة بكفاءة عالية لتحقيق الهدف منها.

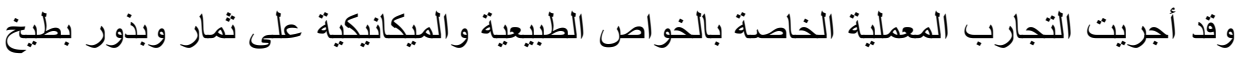
اللب بمعمل مركز ميكنة الأرز بميت الديبة بكفر الثيخ- معهد بحوث الهُبة الهندسة الزراعية خلال الموسم الزراعي 10 ــ م. بينما أجريت التجارب الحقلية لفصل بذور البطيخ في قرية الاتحاد.

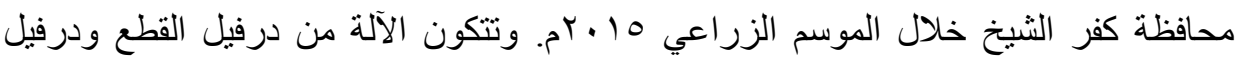

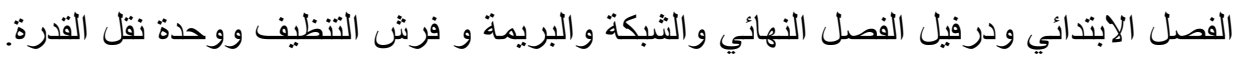

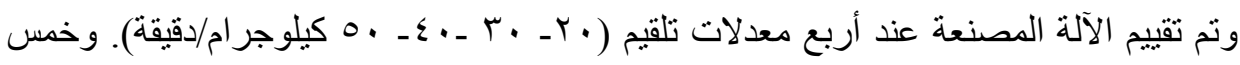

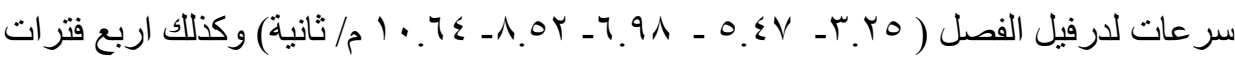

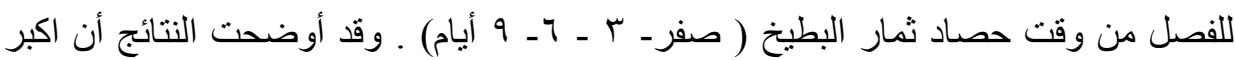

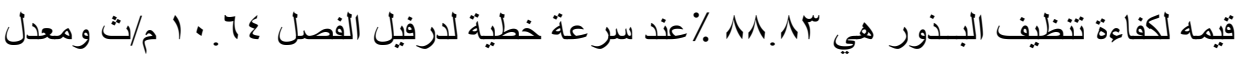

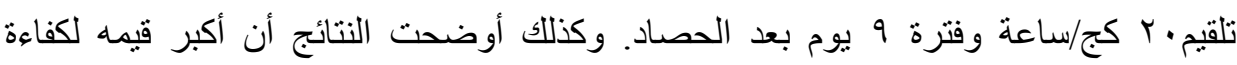

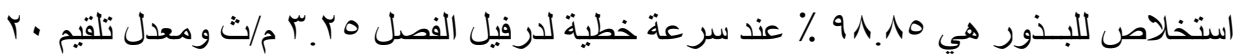




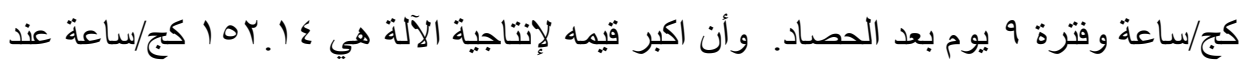

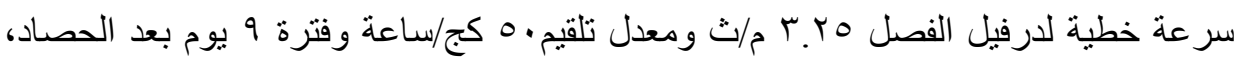

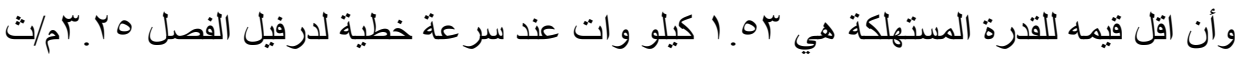

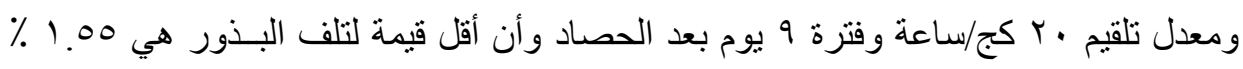

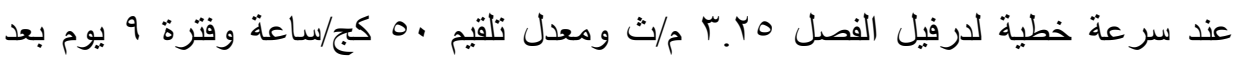

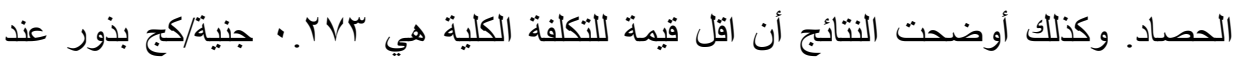

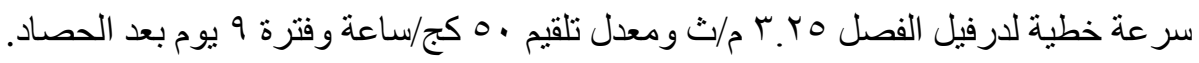

